\title{
BOOK REVIEW: TEMETKEZÉSI SZOKÁSOK A KÖRÖS-TISZA-MAROS KÖZÉN AZ AVAR KOR MÁSODIK FELÉBEN [BURIAL CUSTOMS IN THE REGION BETWEEN THE KÖRÖS, TISZA AND MAROS RIVERS IN THE SECOND HALF OF THE AVAR PERIOD] BY LÍVIA BENDE
}

\author{
FRIGYES SZÜCSI \\ Hungarian Archaeology vol. 9 (2020), Issue 1, pp. 62-65, https://doi.org/10.36338/ha.2020.1.10
}

Livia Bende died before her time, but the book that has been published from her PhD dissertation defended in 2006 deals with the burial customs characteristic of the second half of the Avar period within a clearly defined geographic region, the area between the Körös, Tisza and Maros rivers. Nowadays it is nearly commonplace to mention the outstanding importance of a full-scope regional analysis of a given archaeological period, but Avar period research is still in need of this in connection with the significant areas of the Carpathian Basin. Livia Bende follows the traditions of regional research, but her work is still groundbreaking from several perspectives and indisputably fills a gap in our knowledge. This convincingly underlines the importance of releasing this valuable publication even more than a decade after she defended her dissertation.

Previously, detailed regional examination of burial customs based on extensive collection had usually been limited to the analysis of a single ritual element, as the author points out in her introduction (she highlights the work of Péter Tomka in connection with this). On the one hand, this book points out a gap in Avar period research, and on the other the groundbreaking significance of the author's work underscores the fact that she was not able to compare the area under examination with other regions due to the lack of similar full-scope analyses.

Lívia Bende's doctoral dissertation and the book published from it is considered by a series of

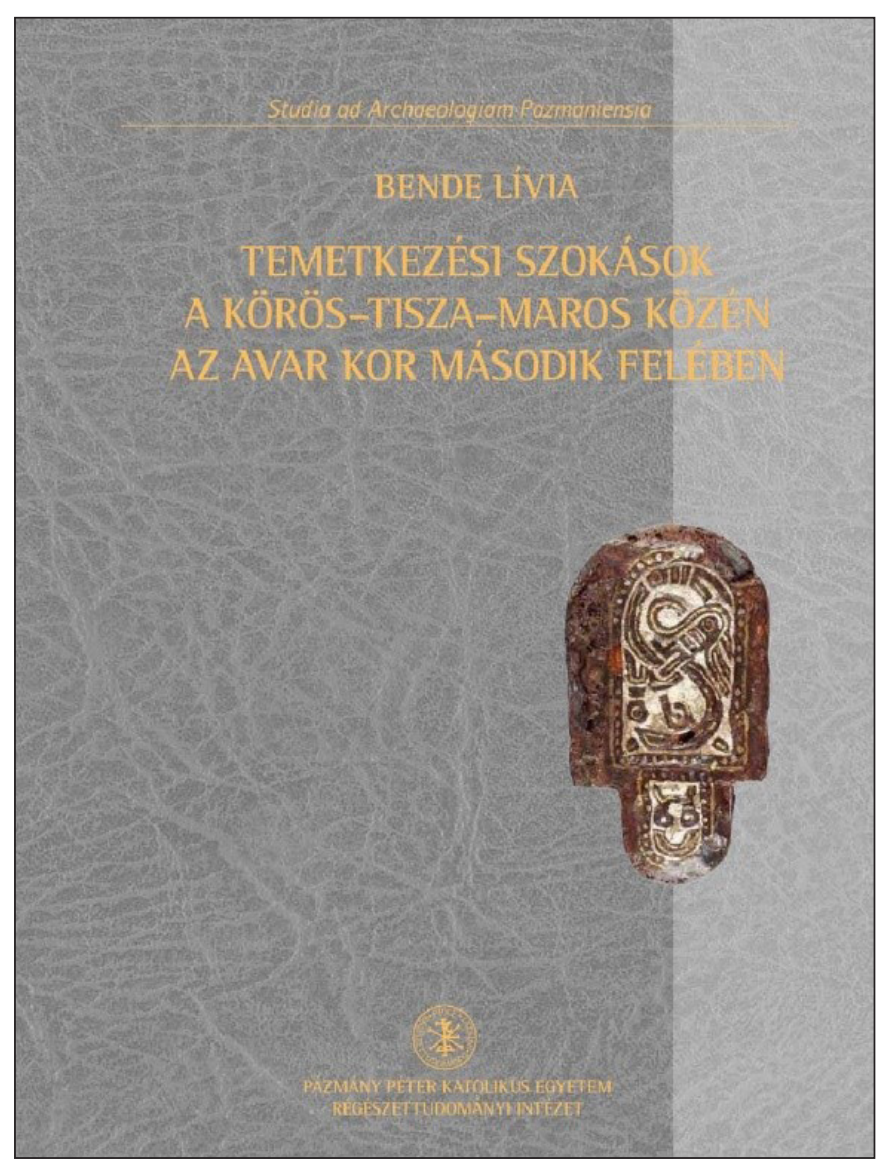

Fig. 1. Temetkezési szokások a Körös-Tisza-Maros közén az avar kor második felében [Burial customs in the region between the Körös, Tisza and Maros rivers in the second half of the Avar period] by Livia Bende.

Studia ad Archaeologiam Pazmaniensia 8. Budapest: Archaeolingua, 2017

\section{Hardcover, 564 pages, with illustrations} ISBN 978-963-9911-95-6 researchers examining Avar period regions to be a fundamental work and an example that should be followed and further developed (BALOGH, 2016, 8; SzÜCSI, 2019a). Research is slowly but surely proceeding towards providing regional elaborations extending to the ritual elements and overall find materials from the whole of the former Avar Khaganate. Ethnographic regions in the Avar period are essentially being outlined in this way before our eyes, but the possibilities of the regional method may go far beyond this. A more precise chronology may be able to be constructed on the basis of the use of object types and fashions in the individual regions, and furthermore in fortunate cases the traces of internal and external migration may 
be understood, based in part on a precise chronology and in part on local "ethnographic" characteristics. Using this method, the author succeeded in differentiating the local populations with Early Avar period roots - who moved from this settlement area in the second half of the 7th century on the basis of the new cemeteries that were opened - as well as the communities that had recently settled along the Tisza River and can be characterized by Middle Avar period material culture. The presence of the Middle Avar material culture supports the origins of the latter groups coming from within the Avar settlement area.

Already from the title, it is clear that the researcher differentiated two eras in the Avar period as opposed to the customary three (Early, Middle and Late Avar periods). The differentiation of two periods is indisputably justified in relation to the area between the Körös, Tisza and Maros rivers, since - as Lívia Bende points out - cemeteries that were used throughout the Avar period cannot be found there. The use of the Early Avar period cemeteries ended in the second half of the 7th century, and at this same time, new cemeteries were put into use in larger numbers in part in areas different from the earlier locations. Understanding the precise chronology of the changes that began in the Avar settlement area around the middle of the 7th century is difficult for researchers even to the present day. Due to this, it is not surprising that the author was not able to determine "precisely when and for what reasons the use of Early Avar cemeteries was abandoned and when the large late cemeteries were established in the second half of the 7th century." This fact in and of itself - the abandonment of Early Avar cemeteries and the opening of new cemeteries - sheds light on the differing development of major territorial units in the Avar period Carpathian Basin. After all, the continuity of use throughout the entire Avar period of the larger cemeteries is quite common to the west of the Danube River (it is sufficient here to point out the cemeteries of Zamárdi and Csákberény and those of the Mezöföld region, where the continuous use of Early Avar period cemeteries can be considered widespread).

The introduction is followed by a catalogue of the graves that serve as the basis of the analysis. The utility and usefulness of the catalogue for research would be increased if it was accompanied by attached pictures, because they would serve to verify the data included in the analysis. It would have been more worthwhile to compile a separate volume or volumes on the grave descriptions appearing in the catalogue, accompanied by illustrations and when possible a separate analysis of the cemeteries.

When the orientation data is provided in most publications, the clear designation of which degrees are included in the given orientation range according to the currently most widespread 360 degree system is lacking. It is commendable that Lívia Bende began Chapter 4, which is devoted to the conclusions that could be drawn from the orientation of the graves, by clearing up this issue. In place of the northeast-southwest or east-west orientation characteristic of the Early Avar period in the area studied, a northwest-southeast orientation became definitive in the Late Avar period. Thus, there was no continuity from this perspective between the Early and Late Avar period. Based on the systematically collected data, the author determined that the groups with different traditions from the communities making burials in the cemeteries could not be differentiated purely on the basis of the orientation of the graves.

Essential important information can be gained in terms of both the beliefs and the social stratification of the former community from the analysis of the grave forms, the size and arrangement of the grave pits, and Chapter 5 of the book is built upon this.

During the analysis of graves with sidewall niches (sub-chapter 5.2), in footnote 231 there is mention of a significant issue, namely that often it cannot be decided whether the "grave pit originally had a sidewall niche or it took this form during the excavation of the grave". Understanding this, we can agree with the statement that despite the seemingly "provocatively few" number of cases, "the role of this grave form could not have been negligible" because "amongst the 10 sites where this phenomenon occurs, all contain large graveyards or graveyard sections".

Figure 2, cited in the sub-chapter on grave structures (5.3) was unfortunately left out of the book, even though it would have significantly aided in understanding the grave structures described by the author. The use of graves with posts varies regionally and numerous data denote important differences, which Lívia Bende also pointed out. Since post-like projections in the walls of the grave were only registered in a minimal number of graves, a total of 21 of the 3,277 , this seems to have been a rare custom in the area 
in question - in contrast to the Transdanubian region for example (SzÜCSI, 2019b, 112). It was apparent to Bende that "large sacrificial animals are not characteristic in these graves" in the area between the Körös, Tisza and Maros rivers, contrasting for example with numerous cases in Transdanubia and the southern part of Upper Hungary (TRUgly, 2008, 82-83; SzÜCSI, 2015, 15-64). Chronological differences also appear between the individual regions of the Carpathian Basin, since it seems that this grave form was characteristic of the area in question in the 8th century. In other words, it appeared here later than in Transdanubia, where examples can be seen from the Early Avar period (SzÜCSI, 2019a, 31) or the area between the Danube and Tisza rivers, where they can be found from the second quarter of the 7th century (BALOGH, 2016, 45).

Lívia Bende paid a great deal of attention to graves with a niche dug from the end of the grave pit (sub-chapter 5.4) because the region between the Körös, Tisza and Maros rivers was the hub of these kinds of burials. Men, women and in rare cases children were buried in this manner. It is an important finding that there are numerous formal variations in the arrangement of graves, but these did not differ from the Early Avar period forms. The author emphasized the connections in terms of burial rites between the graves with a niche dug from the end of the grave pit from the Early Avar period and the older ones from the second half of the Avar period (essentially Middle Avar period). In connection with this, she points out the presence of sacral bones and vertebrae of sheep provided as food offerings, the vessels at the mouth of the niche or next to the skull of the corpse and the partially interred sacrificial animals, although this was in significantly smaller numbers than in the Early Avar period. She noticed that the regularity in the arrangement of the later graves with a niche dug from the end of the grave pit in a row or in a line had chronological significance. The older horizon of the late graves with a niche dug from the end of the grave pit can be registered from the middle of the 7th century to the beginning of the 8th century, and then this burial custom appears again at the end of the Avar period after a break of several generations. It is unknown why they abandoned the creation of these graves for numerous decades despite the continuity of the population using the cemeteries, as well as the explanation for the renaissance of the custom at the end of the 8th century and beginning of the 9th century, even if only in a small number of cases.

Chapter 6 discusses the method of placing the deceased in the grave. The use of coffins can be considered widespread in the Avar period, including the region under study. The author considered the cases when the coffin was in some way protected from contact with the earth used to refill the grave to be extraordinary. The following grave forms served this purpose: graves with a niche dug from the end of the grave pit, graves with sidewall niches and graves with posts. In this sense, the graves with post structures and with sidewall niches took over the place of graves with niches dug from the end of the grave pit. Irregular burials (buried in a compressed form or corpses lying prone) and double or multiple burials appeared in the usual small numbers in Avar period cemeteries.

The examination of the role played in the burial rites by items of apparel and grave good objects is dealt with in Chapters 7 and 8 . However, the analysis did not cover the classification and chronology of the objects found in the graves, which perceptibly limited the results that could be achieved. Despite this, the few sentences - or at most a paragraph - dedicated to the individual object types also contained a great deal of important information and observations. For example, an observation worthy of note is that while in the area east of the Tisza River in the Early Avar period the overwhelming majority of vessels were found next to the skull, in the period under study - the second half of the Avar period - the ceramic vessels were increasingly rarely placed next to the head as time passed (in the later period, their location was in the vicinity of the legs, primarily the feet). Scanty numbers of weapons as grave goods is characteristic of the area and period studied, and the majority of these finds were placed in graves dug in the second half of the 7th century and the first half of the 8th century. Bende examined the burials with equestrian equipment in detail because this custom - while appearing scattered throughout essentially the entire territory of Avaria - is known in the greatest numbers precisely from the region between the Körös, Tisza and Maros rivers or in its vicinity. On the basis of Lívia Bende's definition, "the custom - as its name shows - means the placement of equestrian equipment or elements of this in the grave during burial without placing an entire or partial horse next to the deceased" (see Chapter 8.5). Ninety percent of the burials with equestrian equipment in 
the area studied were men, including those of every age group, but mostly older. The burials with equestrian equipment were often combined with graves with a niche dug at the end of the grave pit.

The analysis of the role in the burial rite played by grave goods related to animals was placed in Chapter 9 , the final chapter before the conclusion. The author differentiated between sacrificial animals and food offerings, which she examined in separate sub-chapters. A difficulty was represented by the fact that no detailed archaeozoological examination has been published for any of the cemeteries in the area under study. However, the researcher came to notable conclusions through the exemplary collection of the results at her disposal. The placement of sacrificial animals in the grave proved to be a decisive part of the burial rite in the area between the Körös, Tisza and Maros rivers. A new element compared to the Early Avar period was the placement of entire animals (cattle, sheep) in the grave, the disappearance of partial sacrificial horses and in the case of partial cattle or sheep sacrifices, they were decapitated instead of chopping off their legs. The presence of cattle and sheep is proof of a lifestyle of large animal husbandry, but poultry was also given an increasing role as a food offering.

It is most welcome that the papers presenting the results of the radiocarbon dating, anthropological and archaeozoological examinations for the Pitvaros-Víztározó cemetery written by Zsuzsanna Siklósi, Gábor Lörinczy, Erika Molnár and István Vörös were published in the appendices of the book. On the basis of the archaeological chronology, the abandonment of the cemetery can be placed in the period around 835-850, but in contrast to this, on the basis of the radiocarbon dating of ten graves relevant from a chronological standpoint, the use of the cemetery had ended already by the end of the 8th century at the latest. Further radiocarbon results that are expected to be published in the near future suggest that this problem goes beyond the Pitvaros cemetery, and the resolution of this contradiction is expected through future research.

The thick volume presented here is outstandingly useful for researchers into the Great Migration period and is evidence of enormous work. Its significance and its essential nature for research into the Avar period is shown by the fact that even one or two years after its issuance fresh publications are already citing it. It stands as a worthy memorial to a researcher who unfortunately passed away too soon.

\section{BIBLIOGRAPHY}

Balogh, Cs. (2016). Régészeti adatok a Duna-Tisza közi avarok történetéhez. [The history of the Avars in the Danube-Tisza Interfluve as reflected in the archaeological record]. Studia ad Archaeologiam Pazmaniensia 6. Budapest: Archaeolingua.

Szücsi, F. (2015). Avar kori temetők Nagyvenyimröl. A Munkácsy utca - Füzfa utcai, a határvölgypusztai és a jármüjavítói temetőrészletek. [Avar Period burial sites at Nagyvenyim. Cemetery fragments from Munkácsy utca - Füzfa utca, Határvölgypuszta and Jármüjavító sites]. Alba Regia 43, 15-64.

Szücsi, F. (2019a). Temetkezési szokások az avar kori Mezőföldön és az 5-10. századi térhasználati és kontinuitási kérdések (Doktori disszertáció). [Funerary customs in the Avar Age Mezőföld (Hungary, EastTransdanubia) and questions of the use of space and continuity in the 5th-10th centuries (PhD Dissertation)]. Pázmány Péter Catholic University, Doctoral School of History, Budapest.

Szücsi, F. (2019b). „Az ismeretlen ismerős”. Új eredmények a csákberény-orondpusztai avar kori temető kutatásából. [„,The unknown acquaintance”. New results of the research of the Avar cemetery at CsákberényOrondpuszta]. In Sudár B. \& Türk A. (eds.), Hadak útján. A népvándorláskor fiatal kutatóinak XXIX. konferenciája. Budapest, 2019. november 15-16. Absztraktkötet (p. 112). Studia ad Archaeologiam Pazmaniensia 14. - Magyar Östörténeti Témacsoport Kiadványok 7. Budapest: Bölcsészettudományi Kutatóközpont Magyar Östörténeti Témacsoport - Martin Opitz Kiadó - PPKE BTK Régészettudományi Intézet.

Trugly, S. (2008). A Komárom-hajógyári avar temető és telep. [The Avar cemetery and settlement in Komárom-Hajógyár]. Budapest: Martin Opitz Kiadó. 